PONTIFÍCIA UNIVERSIDADE CATÓLICA DO RIO DE JANEIRO

\title{
A Percepção do Consumidor sobre a Nova Embalagem utilizada nas Lasanhas e Nuggets da Sadia
}

\section{Caio Goes Moreirão}

Trabalho de Conclusão de Curso

CENTRO DE CIÊNCIAS SOCIAIS - CCS

Departamento de AdMinistração

Graduação em Administração de Empresas 


\section{Caio Goes Moreirão}

\section{A Percepção do Consumidor sobre a Nova Embalagem Utilizada nas Lasanhas e Nuggets da Sadia}

Trabalho de Conclusão de Curso

Trabalho de Conclusão de Curso, apresentado ao programa de graduação em Administração da PUC-Rio como requisito parcial para a obtenção do título de graduação em Administração.

Orientador (a): Daniel Kamlot 


\section{Resumo}

Em julho de 2017 a empresa BRF (dona das marcas Sadia, Perdigão, Qualy, entre outras) mudou a embalagem de seus pratos prontos e seus empanados domésticos. $O$ que antes eram embalagens rígidas e de papelão, se tornaram embalagens maleáveis e de plástico. A empresa tomou a decisão de alterar suas embalagens a fim de melhorar a experiência de seus consumidores, de aumentar a eficiência de seus promotores de vendas e de diminuir o número de perdas por embalagens danificadas. O objetivo deste estudo é buscar entender como funciona o comportamento do consumidor de lasanhas prontas e de nuggets, além de compreender como o consumidor percebeu a mudança anteriormente citada na embalagem das lasanhas $e$ dos nuggets da Sadia.

Palavras- chave: comportamento do consumidor; lasanha; nuggets; embalagem 


\section{Sumário}

1. Introdução 1

2. Referencial Teórico 4

2.1. Conceito de Comportamento do Consumidor 4

2.2. Percepção do Consumidor e sua Interpretação 4

2.3. Inovação 6

$\begin{array}{ll}\text { 2.4. Embalagem } & 7\end{array}$

3. Metodologia 9

4 . Apresentação e análise dos resultados $\quad 11$

4.1. Descrição dos Resultados 11

4.2. Análise dos resultados $\quad 21$

5. Conclusões 28

6. Referências Bibliográficas 29 


\section{Introdução}

Em junho de 2017, a Sadia, empresa de alimentos fundada em 1944 e hoje pertencente ao grupo BRF que além de contemplar esta marca, conta com a Perdigão e a Qualy em seu portfólio nacional, começou a embalar seus pratos prontos e seus empanados domésticos em embalagens maleáveis e feitas de plástico, deixando a tradicional caixa de papelão de lado. (EMBALAGEMMARCA, 2017)

A empresa foi fundada na cidade de Concórdia, SC, por Attilio Fontana. Na década de 60 ela atinge uma marca de 1 milhão de frangos abatidos e começa a ganhar fama por seus hambúrgueres de carne bovina e seus perus. Por volta da década de 70, o seu mascote, que permanece como marca registrada da empresa até os dias de hoje, é lançado para o público, como podemos ver na Figura 1, mascote este que foi nomeado como Lek Trek pelos próprios consumidores da marca na década de 80, década também marcada pelo lançamento dos nuggets, steaks, hambúrgueres e almôndegas de frango. Na década seguinte, os fatos mais relevantes foram o lançamento de pratos prontos que poderiam ir ao forno de micro-ondas, elétrico ou convencional, como a tradicional lasanha à bolonhesa e suas pizzas prontas. Já no século XXI, a empresa ficou em evidência pela sua fusão com, até então, sua maior concorrente, a Perdigão, para juntas formarem a BRF (Brasil Foods). (AVICULTURA INDUSTRIAL, 2016) 


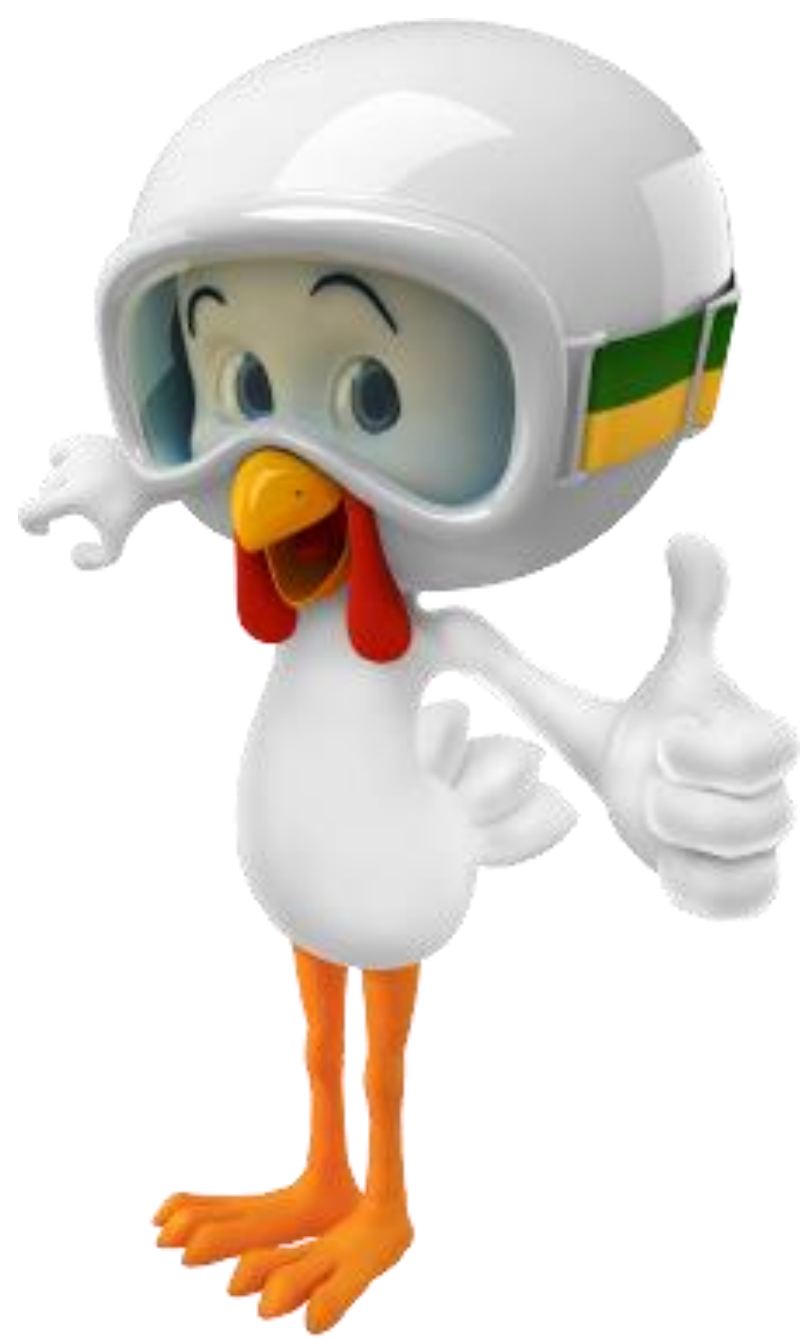

Figura 1: Lek Trek que se mantém até os dias de hoje como referência da Sadia. Fonte: Sadia.com.br, 2018.

Após todos esses anos (mais de 70 anos de existência), a Sadia não perde sua relevância no mercado, sendo considerada por 5 anos consecutivos, segundo a Folha de São Paulo (2017), a marca mais lembrada pelos consumidores na categoria de congelados com 32\% de mind share. Além disso, apenas para ressaltar a importância da marca no mercado de alimentos, de acordo com o estudo Consumer Watch Express Shopper da Kantar Worldplane (2014), o faturamento deste mercado na América Latina cresceu em 24\% e, em média, 33\% dos consumidores optam por produtos desse mercado no continente, enquanto no Brasil isso ocorre com $61 \%$ dos consumidores.

Falando sobre a alteração da embalagem de alguns produtos da categoria de congelados da Sadia, o que antes era uma embalagem dura e de papelão passou a ser uma embalagem de plástico e flexível, como podemos observar na Figura 2. 
Esta embalagem foi selecionada pela empresa com o intuito de agregar mais valor percebido aos seus produtos, pois a mesma ocupa menos espaço no freezer do consumidor e não rasgam nem molham, como as antigas embalagens faziam.
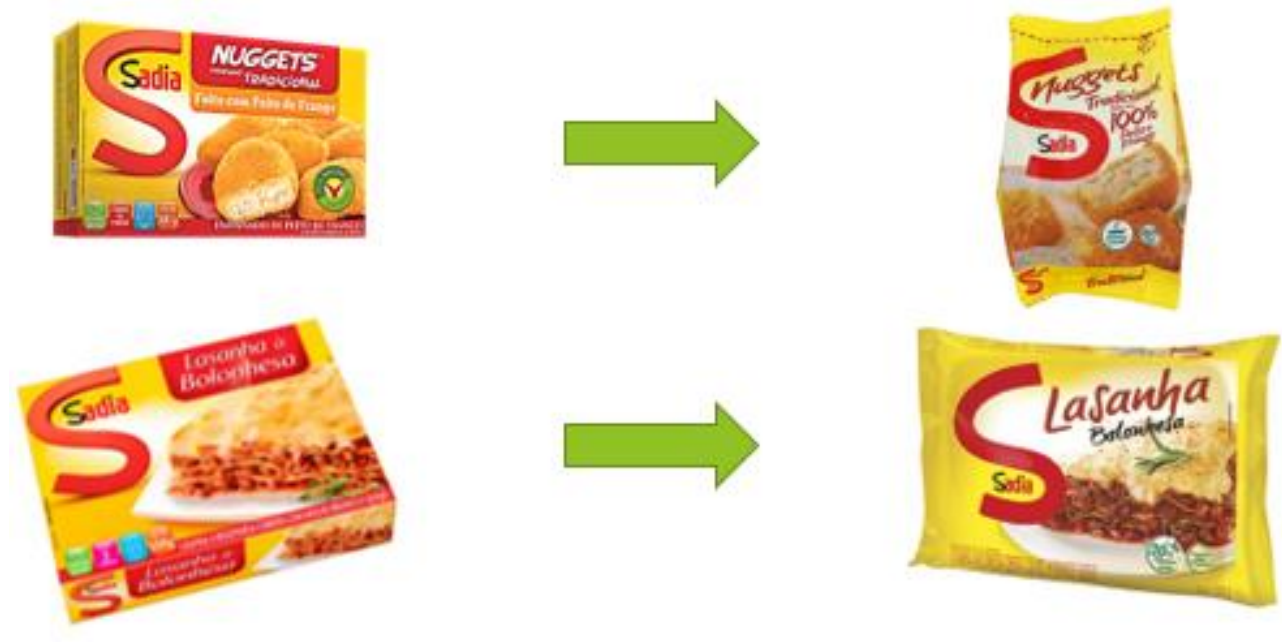

Figura 2: Demonstração das novas embalagens. Fonte: Acervo pessoal.

Segundo Geraldo Cofcewicz, gerente de pesquisa e desenvolvimento de embalagens da BRF, em entrevista à revista EmbalagemMarca em maio de 2017, a embalagem vem propondo mais agilidade para os promotores realizarem a organização das gôndolas no ponto de venda, além de facilitar o armazenamento do produto no freezer dos consumidores, por ser mais maleável e flexível, algo que, segundo Cofcewicz (2017), principalmente os consumidores de empanados sentiam falta, pois "ao remover o cartucho para armazenar apenas seu conteúdo, reduzindo o espaço ocupado, os clientes perdiam a informação sobre o prazo de validade e as sugestões de preparo".

Após todas estas afirmações de Cofcewicz (2017), qual terá sido a percepção dos consumidores a respeito das alterações na embalagem realizadas recentemente pela Sadia?

O objetivo final do estudo é nos ajudar à concluirmos se todo o risco que a BRF correu alterando a embalagem de suas lasanhas prontas e nuggets da Sadia para embalagens que o consumidor não esteja acostumado foi válido ou não.

A análise será delimitada para consumidores do Estado do Rio de Janeiro e só serão pesquisados a percepção dos consumidores a respeito da alteração da embalagem da lasanha Sadia e do nuggets Sadia. 


\section{Referencial Teórico}

Neste tópico são apresentados e discutidos aspectos conceituais e estudos relacionados ao tema e estudo em investigação e que servirão de base para a análise realizada.

\subsection{Conceito de Comportamento do Consumidor}

Para entendermos como os consumidores interpretaram as novas embalagens da Sadia, primeiro devemos entender como os consumidores se comportam no geral.

De acordo com Solomon (2012), o conceito de comportamento do consumidor se baseia nos processos em que o consumidor se envolve em momentos de escolher, comprar ou usar produtos e serviços, variando desde a compra de apenas um lanche indo até a compra de uma casa de praia ou um passeio de barco.

O conceito busca analisar todas as variáveis que influenciam o consumidor, sendo elas de cunho social, racial, geográfico, entre outros, a fim de definir qual é a melhor estratégia possível a ser tomada pela empresa.

As empresas investem neste tipo de estudo a fim de atrair a atenção de seus clientes para uma primeira compra, além de desenvolver fidelidade, criar um laço muitas das vezes emocional e gerar boca-a-boca positivo que não tem custo para a companhia e que muitas das vezes é mais eficaz do que muitas das campanhas de marketing que demandam um alto investimento.

\subsection{Percepção do Consumidor e sua Interpretação}

Indo mais a fundo no estudo de comportamento do consumidor, vamos entender melhor a diferença entre sensação e percepção.

Segundo Solomon (2012), as sensações são os estímulos básicos que recebemos pelos 5 sentidos (visão, audição, olfato, tato e paladar) englobando as cores que vemos, texturas e sabores que sentimos, música que escutamos, entre outros. Quanto à percepção, ela é o processo pelo qual as pessoas 
interpretam estas sensações, ou seja, por meio da percepção cada um de nós dá um significado particular aos estímulos que recebemos.

Nós recebemos estímulos a todos os momentos, mas são poucos os que realmente chamam a nossa atenção. Dentre os que conseguimos perceber, a quantidade de estímulos que processamos é ainda menor e, para dificultar ainda mais a vida das empresas, graças ao nosso background, expectativas e necessidades cada pessoa interpreta cada estímulo de uma forma diferente, por isso a tarefa de conseguir passar a mensagem que se pretende para 0 consumidor é tão difícil.

A interpretação é o que define como "lemos" estes estímulos, é ela que define o que o consumidor irá pensar sobre determinado assunto.

De acordo com a psicologia de Gestalt, segundo Avellar e Duarte (2015), nosso cérebro interpreta os estímulos segundo 5 princípios, sendo eles:

- Proximidade: Caso se queira destacar algum elemento que tenha muitos similares ao seu redor dos demais, é necessário você posicioná-lo em um local diferenciado (Ex: algum ponto mais alto) para que não seja demandado tanto esforço do consumidor para que o mesmo consiga percebê-lo;

- Similaridade: Caso produtos tenham semelhanças entre si, eles serão percebidos como parte de um único grupo;

- Figura e fundo: algumas imagens de uma mesma embalagem são percebidas com mais destaque do que o restante, podendo haver inclusive uma diferença de profundidade entre as mesmas, por mais que estejam no mesmo plano;

- Simetria: Tendemos a comparar o posicionamento de um objeto sempre ao centro;

- Fechamento: Costumamos fechar espaços que estejam vazios baseado em experiências prévias.

Analisando os princípios citados acima, o princípio que mais pode ter afetado a BRF com a mudança das embalagens em relação à percepção dos seus consumidores de nuggets e lasanha da Sadia é o da Similaridade, visto que os principais concorrentes dela continuam utilizando embalagens similares entre si (com exceção da Forno de Minas e da Perdigão para lasanhas prontas), o que pode interferir no processo de procura do produto pelo consumidor, fazendo que os produtos da Sadia não sejam reconhecidos no ponto de vendas. 


\subsection{Inovação}

Para conseguirmos analisar como o consumidor interpretou a inovação implementada pela Sadia, iremos entender um pouco sobre os tipos existentes de inovação e quais são suas principais características.

Segundo Hisrich (2014) existem três tipos de inovação denominando-as em ordem decrescente de exclusividade como a inovação revolucionária, inovação tecnológica e a inovação comum como podemos ver no Gráfico 1.

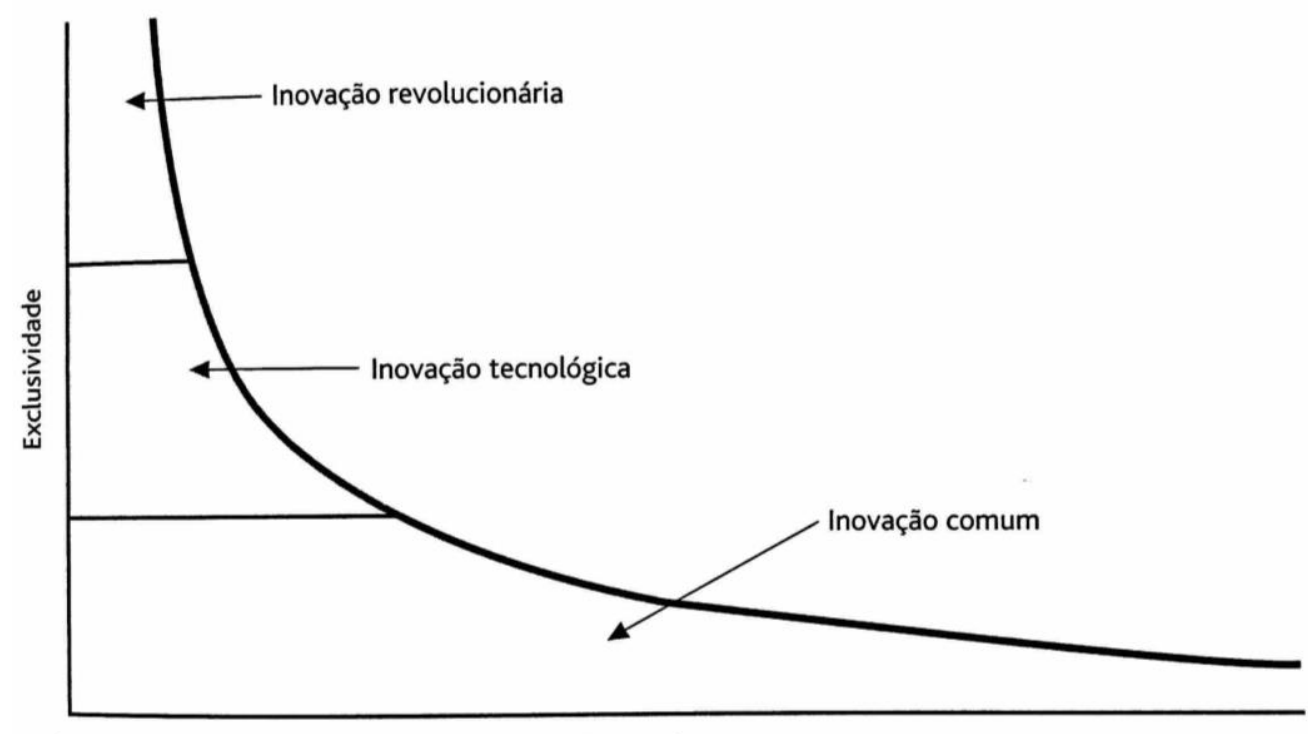

Número de eventos

Gráfico 1: Imagem que demonstra a diferença de um tipo de inovação para outro. Fonte: Hisrich, 2014.

O primeiro tipo de inovação é o mais raro de todos e geralmente é o tipo de inovação que tem a possibilidade de revolucionar um mercado inteiro e muitas das vezes sendo protegidas por patentes, tendo como exemplos a internet, o avião e a televisão.

Já as inovações tecnológicas, apesar de não representarem um avanço tão grande quanto as inovações revolucionárias, ainda assim são bastante representativas, pois trazem progresso na área do produto, sendo o celular portátil, o computador pessoal e o avião a jato exemplos típicos deste tipo de inovação.

Para fechar os tipos de inovação, vem a inovação comum, que busca adaptar os produtos a realidades que se adequam mais às dos seus usuários e consumidores. O que diferencia esse tipo de inovação das demais é que, ao invés da sua criação ter origem de uma grande oferta de tecnologia, ela é desenvolvida por uma pressão vinda do mercado e exemplos deste tipo de 
inovação podem ser as novas embalagens da lasanha e do nuggets da Sadia, como a bicicleta elétrica e capas de proteção para celulares com baterias externas.

Além destes 3 tipos de inovação, ainda segundo Hisrich (2014), temos três categorias para classificarmos novos produtos do ponto de vista do consumidor, sendo elas a inovação contínua, inovação dinamicamente contínua e a inovação descontínua, inclusive estas categorias nos ajudam a identificar o nível de mudança de comportamento que o consumidor teve com tal inovação.

Começando pela inovação contínua, são produtos que tiveram suas embalagens, seus tamanhos ou seus formatos alterados e cuja influência no comportamento do consumidor é quase inexistente, tendo como exemplo lançamentos de novas coleções de roupas e até mesmo automóveis.

Indo para a inovação dinamicamente contínua, são produtos que geram um certo nível de perturbação aos padrões do consumidor, mas que não são tecnologias totalmente novas. Um exemplo disso foi quando os aparelhos de telefone móvel começaram a ter acesso à internet.

Por fim, temos a inovação descontínua, que representa produtos que são totalmente novos para os consumidores, além de demandarem um nível de aprendizado gigantesco dos mesmos. Alguns exemplos podem ser as mídias sociais e, novamente, a própria internet, sendo ambos os produtos algo que revolucionou a estilo de vida de toda a sociedade moderna.

\subsection{Embalagem}

O principal objetivo deste estudo é identificarmos a percepção do consumidor a respeito da mudança de embalagem da lasanha e do nuggets da Sadia, portanto devemos entender conceitualmente o que é uma embalagem e qual é sua importância.

Para Kotler (2012, página 368), uma embalagem pode ser definida "como o conjunto de atividades de design e produção do recipiente que envolve um produto", além de ser "o primeiro contato do comprador com o produto. Se eficiente, atrai o consumidor e estimula a escolha pelo produto" funcionando como um "comercial de 5 segundos".

As embalagens são grandes ferramentas de marketing e desempenham diferentes funções para o consumidor. No autosserviço (local de venda para o consumidor final dos produtos estudados em questão), a embalagem tem 0 
desafio de chamar a atenção do consumidor dentre milhares de produtos ao seu redor e conseguir transmitir informações como a marca, descrever o produto e ainda possuir um visual convidativo ao shopper.

Para Kotler (2012, página 368), as embalagens devem ser capazes de "identificar a marca", "transmitir informações descritivas e persuasivas", "facilitar o transporte e proteção do produto", "fornecer informações sobre a armazenagem em casa" e "fornecer orientações sobre o consumo do produto", mas para o estudo em questão os principais temas a serem abordados serão as questões de identificação da marca e de transmissão de informações descritivas e persuasivas, em qual iremos realizar uma pesquisa para tentar identificar se os desenvolvedores das novas embalagens da Sadia tiveram sucesso ou não mudando seu material de produção, além de seu formato e seu desenho. 


\section{Metodologia}

Para conseguirmos identificar como o consumidor percebeu (ou não) a mudança de embalagem do nuggets e da lasanha da Sadia, iremos realizar uma pesquisa descritiva que, segundo Vergana (2004), ela pode "estabelecer correlações entre variáveis e definir sua natureza". Sendo assim, por meio dela buscaremos identificar se há uma correlação entre as novas embalagens e o consumo dos produtos por parte de seus clientes finais.

Tratando da amostra que será estudada, ela será não-probabilística por acessibilidade que, novamente segundo Vergana (2004) ela seleciona elementos por facilidade de acesso. Como $61 \%$ da população brasileira consume produtos congelados, ou seja, mais da metade da população, foi considerado suficiente realizarmos uma pesquisa sem um público-alvo definido, lembrando que foi escolhido ser uma pesquisa por acessibilidade pela facilidade de acesso à um determinado grupo de pessoas.

Um questionário com 13 perguntas (sendo 2 delas abertas e as demais fechadas) foi realizado de maneira online por meio da ferramenta Qualtrics e contou com 67 respostas no mês de maio de 2018 .

O questionário começa com duas perguntas abertas solicitando aos entrevistados descreverem de maneira breve a embalagem de lasanhas prontas e a embalagem de nuggets que ele compra no mercado. Estas perguntas iniciais tinham como objetivo identificar quais são as expectativas do consumidor de maneira ampla quando vai ao mercado comprar estes dois produtos, evitando com que o entrevistado fosse estimulado a responder qualquer pergunta de forma manipulada.

As 4 seguintes perguntas são perguntas gerais afim de identificar características genéricas dos entrevistados, como sexo, idade, renda e profissão.

As 6 demais perguntas buscam entender o comportamento do consumidor que compra lasanhas prontas e/ ou nuggets no mercado, levantando informações de frequência de compra, as características que mais chamam atenção do consumidor durante a compra, se o consumidor trocaria sua marca preferida por uma outra caso a concorrência tivesse uma embalagem mais 
prática e também foi levantado se o consumidor sabia da alteração da embalagem da lasanha pronta e do nuggets da Sadia e como isso afetaria em seu processo decisório de compra. 


\section{Apresentação e análise dos resultados}

Neste capítulo iremos descrever os dados coletados e em seguida analisalos afim de compreender como o consumidor final interpretou esta alteração nas embalagens de lasanhas prontas e de nuggets da Sadia.

\subsection{Descrição dos Resultados}

Abaixo, no Painel 1 temos as informações relacionadas a gênero, faixa de renda e faixa etária dos entrevistados e na Tabela 1 temos as profissões indicadas pelos mesmos.

\begin{tabular}{|lr|lr|}
\hline \multicolumn{2}{|c|}{ Gênero } & \multicolumn{1}{c|}{ Faixa de Renda } \\
\cline { 1 - 2 } Masculino & $62 \%$ & $0-2.000$ reais & $2 \%$ \\
Feminino & $38 \%$ & $2.001-5.000$ reais & $8 \%$ \\
\cline { 1 - 1 } \multicolumn{2}{|c|}{ Faixa Etária } & $5.001-10.000$ reais & $26 \%$ \\
\cline { 1 - 1 } $0-18$ anos & $2 \%$ & $10.001-15.000$ reais & $18 \%$ \\
$19-25$ anos & $45 \%$ & $15.001-20.000$ reais & $23 \%$ \\
$26-32$ anos & $17 \%$ & 20.001 reais ou mais & $24 \%$ \\
$33-40$ anos & $20 \%$ & \multicolumn{2}{|}{} \\
41 anos ou mais & $17 \%$ & &
\end{tabular}

Painel 1: Perfil da Amostra. 


\begin{tabular}{|lr|}
\hline \multicolumn{2}{|c|}{ Profissäo } \\
\hline Estudante & $39 \%$ \\
Vendedor & $7 \%$ \\
Administrador & $5 \%$ \\
Advogado & $5 \%$ \\
Estagiário & $5 \%$ \\
Comerciante & $4 \%$ \\
Empresária & $4 \%$ \\
Gerente comercial & $4 \%$ \\
Jornalista & $4 \%$ \\
Publicitário & $4 \%$ \\
Aposentada & $2 \%$ \\
Artista Plástica & $2 \%$ \\
Assistente administrativo & $2 \%$ \\
Bancário & $2 \%$ \\
Consultor financeiro & $2 \%$ \\
Cozinheiro & $2 \%$ \\
Dentista & $2 \%$ \\
Economista & $2 \%$ \\
Engenheiro & $2 \%$ \\
Jogador de pôquer & $2 \%$ \\
Psicóloga & $2 \%$ \\
Técnico químico & $2 \%$ \\
\hline
\end{tabular}

Tabela 1: Perfil da Amostra.

Agora falando dos resultados da pesquisa, ao analisarmos a primeira parte onde foram usadas duas perguntas abertas ("Descreva brevemente uma embalagem de lasanha pronta que você compra no mercado" e "Descreva brevemente uma embalagem de nuggets que você compra no mercado"), obtivemos 56 respostas para cada pergunta, podendo encontra-las abaixo nas Tabelas 2 e 3 (lasanhas prontas) e Tabelas 4 e 5 (nuggets): 


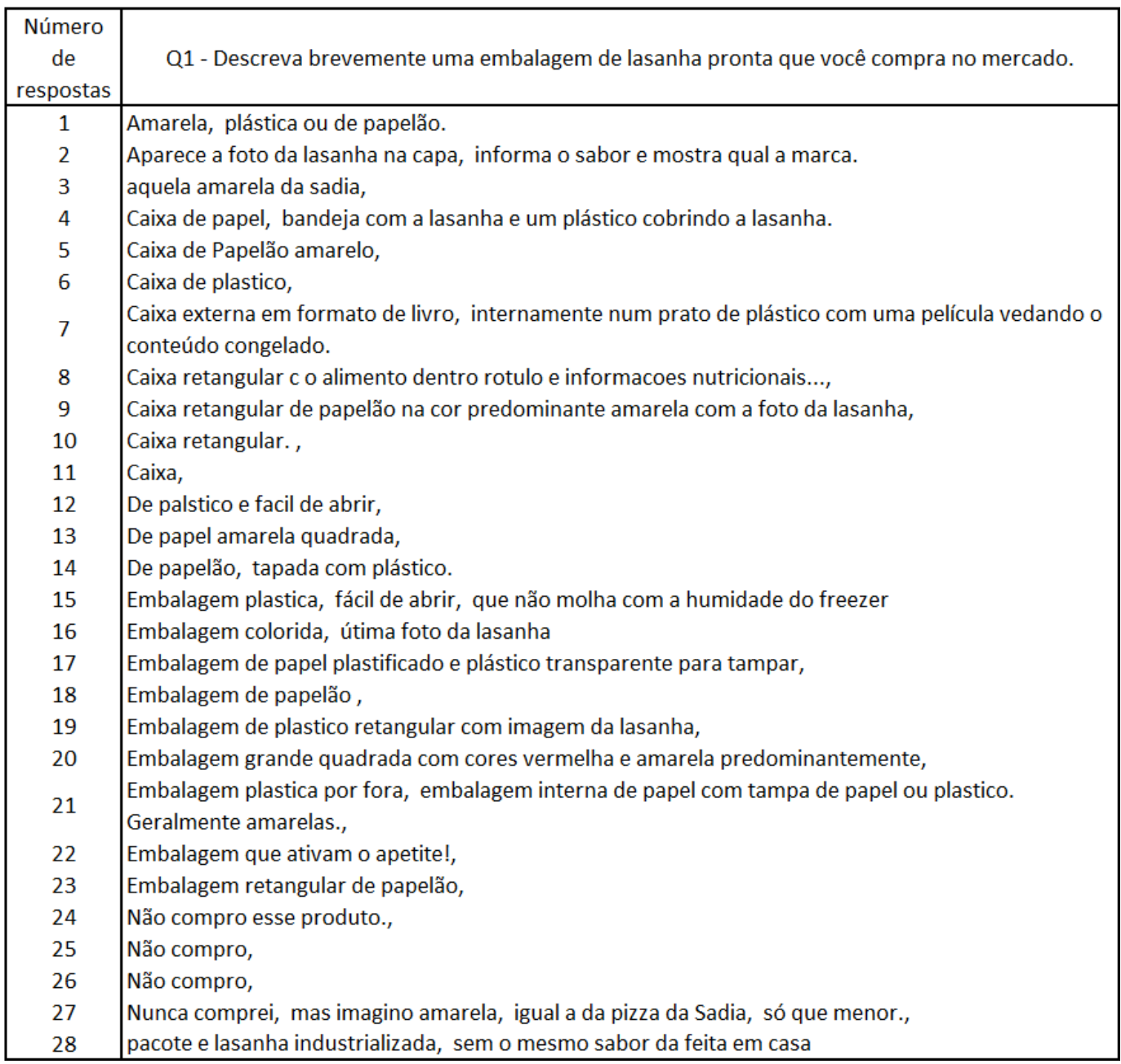

Tabela 2: Respostas da pergunta "Descreva brevemente uma embalagem de lasanha pronta que você compra no mercado". 


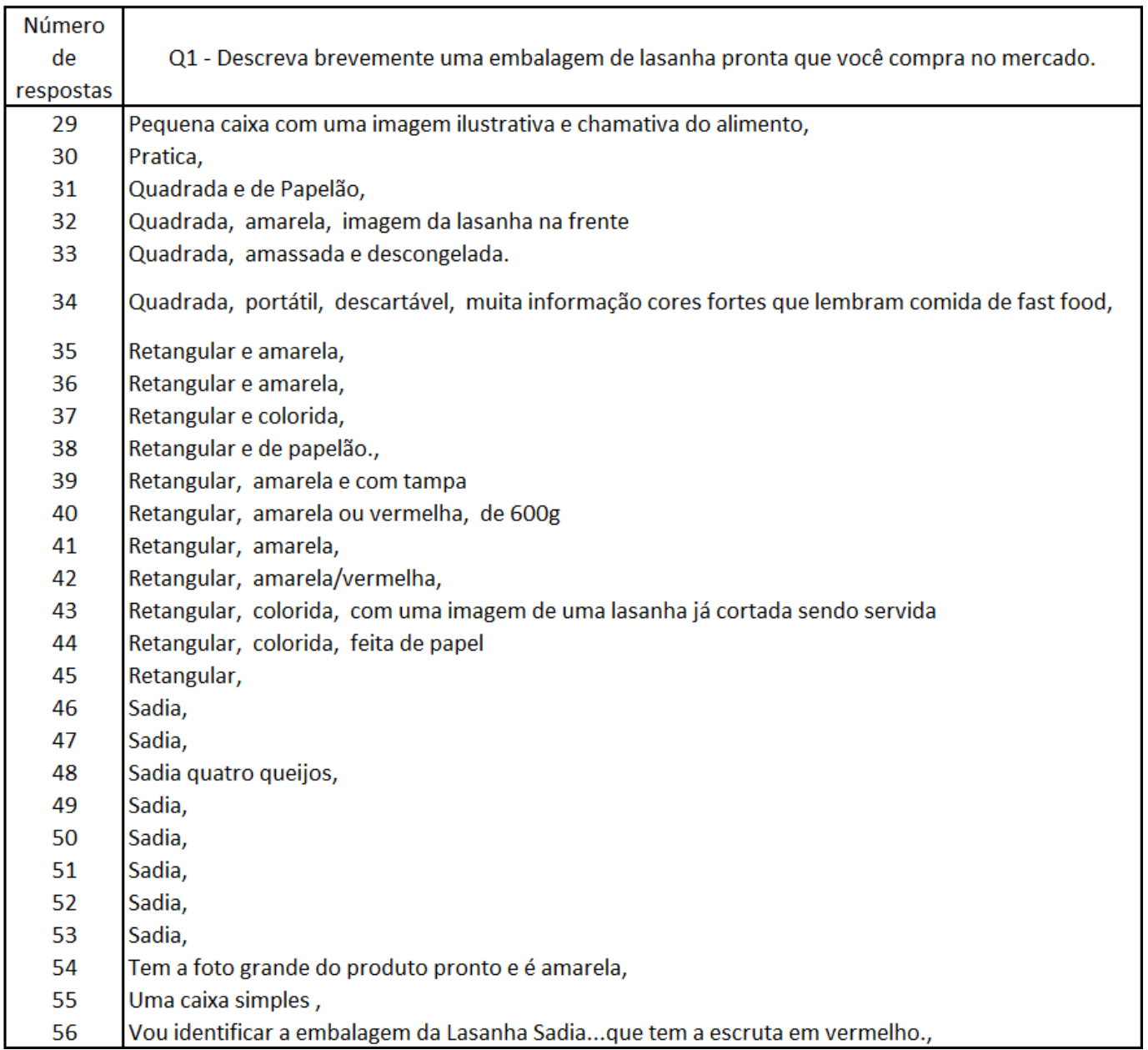

Tabela 3: Respostas da pergunta "Descreva brevemente uma embalagem de lasanha pronta que você compra no mercado". 


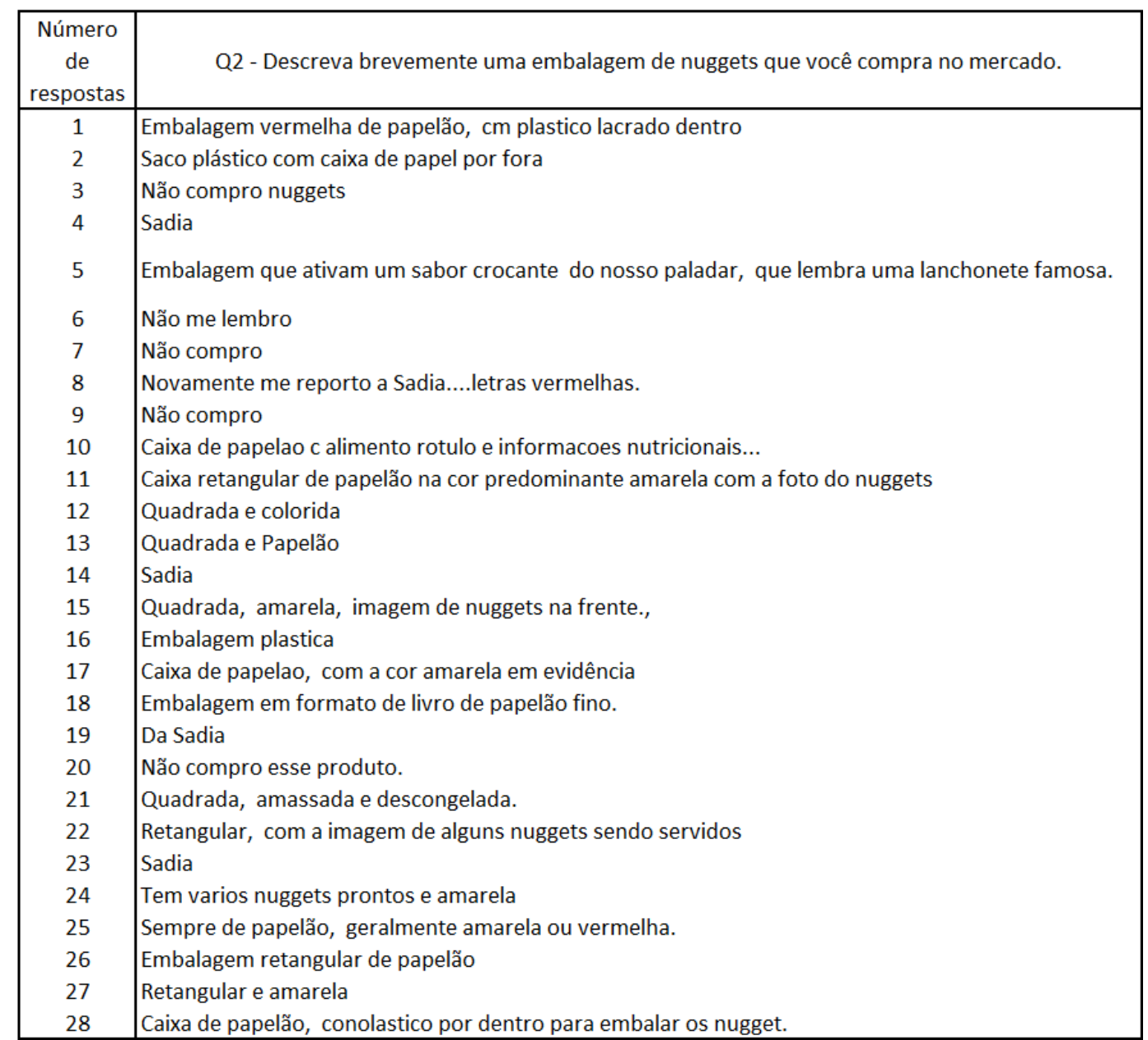

Tabela 4: Respostas da pergunta "Descreva brevemente uma embalagem de nuggets que você compra no mercado". 


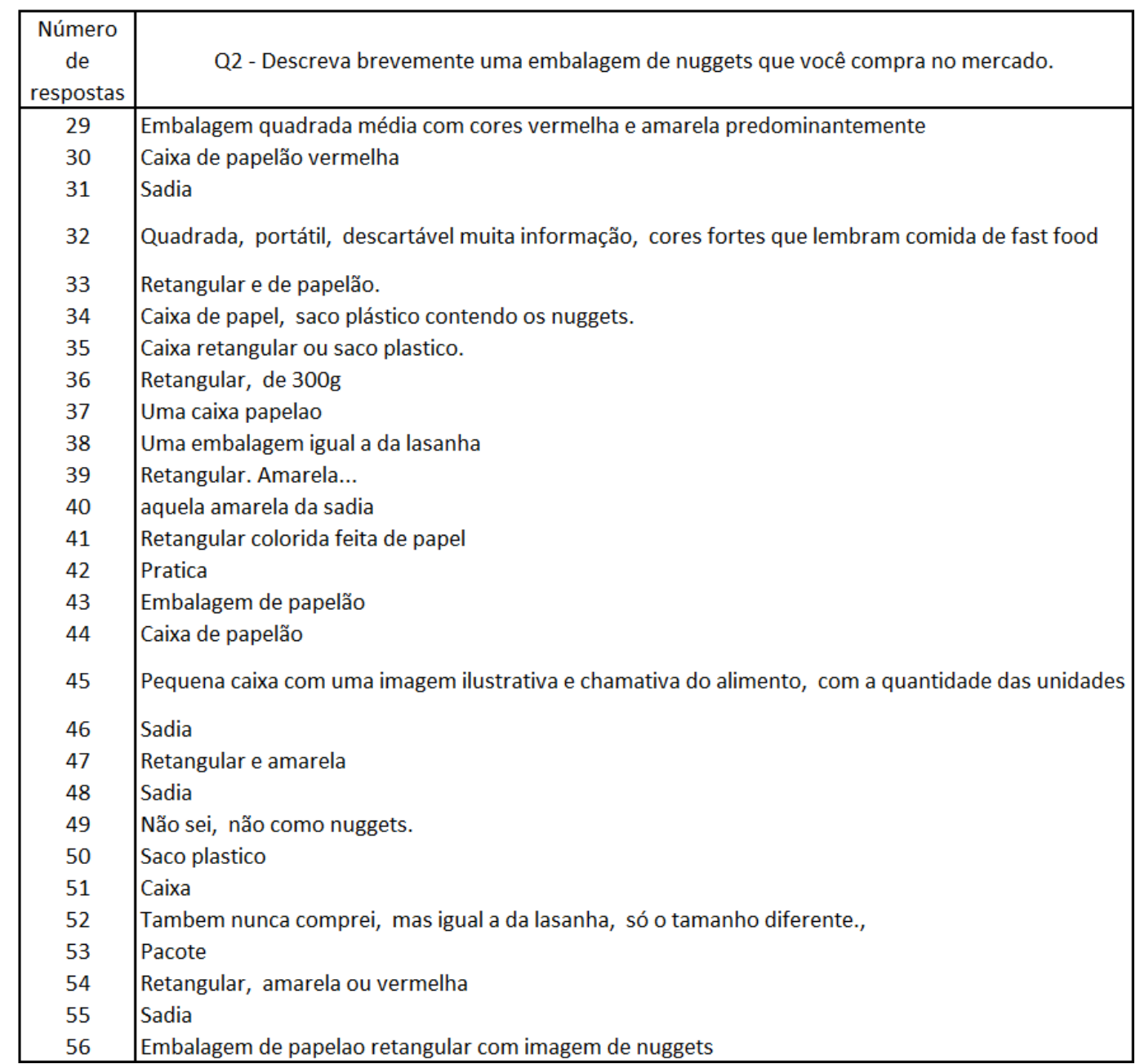

Tabela 5: Respostas da pergunta "Descreva brevemente uma embalagem de nuggets que você compra no mercado".

Indo para o último bloco de perguntas, temos a pergunta "Com que frequência você compra alimentos congelados (lasanhas prontas e/ou nuggets)?" e podemos verificar que a maioria dos entrevistados (45\%) compra estes itens entre 1 a 2 vezes por semana enquanto $36 \%$ não consome estes itens (o que condiz com os dados de mercado já apresentado anteriormente que dizem que $61 \%$ da população consume alimentos congelados) como podemos observar no gráfico na Gráfico 2: 


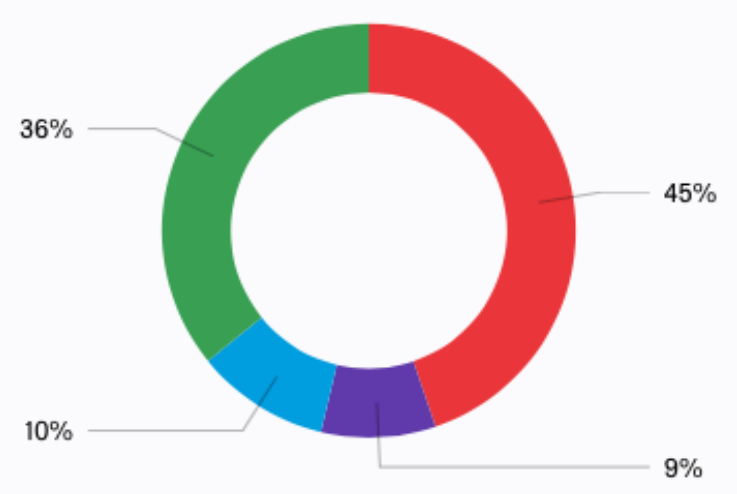

Gráfico 2: Respostas da pergunta "Com que frequência você compra alimentos congelados (lasanhas prontas e/ou nuggets)?".

Após isso, questionei de maneira genérica quais características de uma embalagem chamam mais a atenção do entrevistado independente de produto quando ele está no mercado por meio da pergunta "Ordene em ordem decrescente (maior para menor) as características de embalagens que mais chamam sua atenção no mercado" e os resultados podemos ver abaixo na Tabela 6.

\begin{tabular}{|c|c|c|c|c|c|c|c|c|c|}
\hline \# & Field & 1 & & 2 & & 3 & & 4 & \\
\hline 1 & Cor & $25,76 \%$ & 17 & $39,39 \%$ & 26 & $16,67 \%$ & 11 & $18,18 \%$ & 12 \\
\hline 2 & Material da embalagem & $24,24 \%$ & 16 & $18,18 \%$ & 12 & $33,33 \%$ & 22 & $24,24 \%$ & 16 \\
\hline 3 & Formato da embalagem & $15,15 \%$ & 10 & $15,15 \%$ & 10 & $28,79 \%$ & 19 & $40,91 \%$ & 27 \\
\hline 4 & Rótulo da embalagem & $35,38 \%$ & 23 & $27,69 \%$ & 18 & $20,00 \%$ & 13 & $16,92 \%$ & 11 \\
\hline
\end{tabular}

Tabela 6: Respostas da pergunta "Ordene em ordem decrescente (maior para menor) as características de embalagens que mais chamam sua atenção no mercado".

Buscando saber se o consumidor alguma vez deixou de comprar a lasanha pronta e/ ou o nuggets da Sadia no mercado por não reconhece-los, realizei a pergunta "Em algum momento você deixou de comprar a lasanha ou o nuggets da Sadia por não reconhecê-los no mercado?" que teve sua resposta dada no Gráfico 3 abaixo: 


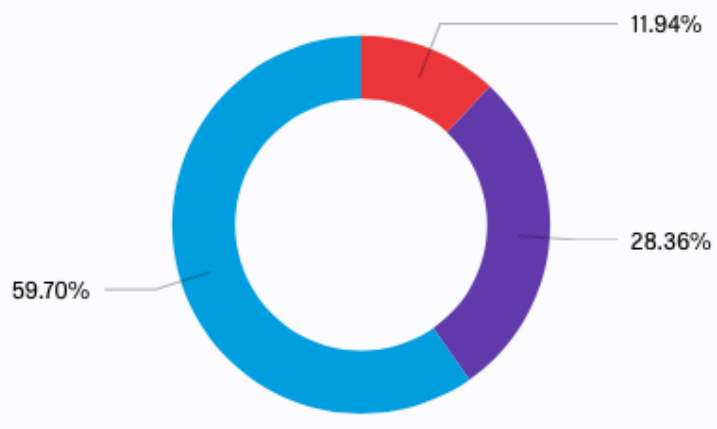

Sim Talvez Não

Gráfico 3: Respostas da pergunta "Em algum momento você deixou de comprar a lasanha ou o nuggets da Sadia por não reconhecê-los no mercado?”.

Para entender mais afundo o comportamento do consumidor de lasanhas prontas e nuggets, perguntei quais as características mais chamam a atenção deles quando vão ao mercado à procura destes 2 itens por meio das perguntas "Quando você procura por lasanhas prontas no mercado, o que mais chama sua atenção?" e "Quando você procura por nuggets no mercado, o que mais chama sua atenção?" e obtive as seguintes respostas olhando o Gráfico 4 e Gráfico 5:

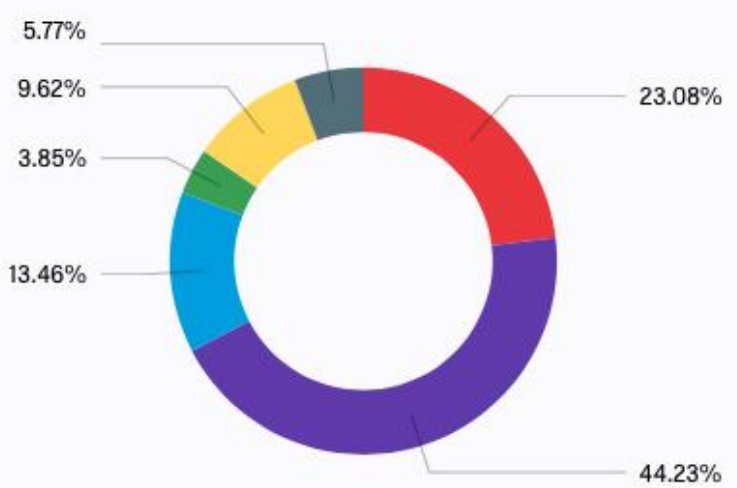


Gráfico 4: Respostas da pergunta "Quando você procura por lasanhas prontas no mercado, o que mais chama sua atenção?".

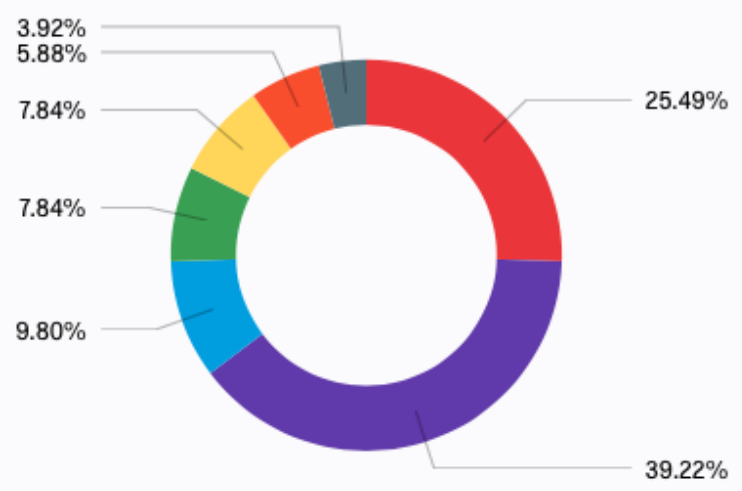

A tradicional embalagem retangular de papelão

Alguma marca específica

O mix de sabores disponíveis

O espaço destinado à uma determinada marca

As informações nutricionais do alimento

peso do produto

Outro

Gráfico 5: Respostas da pergunta "Quando você procura por nuggets no mercado, o que mais chama sua atenção?".

Lembrando que o campo "Outros" estava aberto em ambas as perguntas, abaixo segue as respostas dos mesmos para cada uma na Tabela 7 e na Tabela 8:

\section{Outro}

Como está acondicionada é o estado do produto. Validade.

\section{A integridade da embalagem}

\section{Preço}

Tabela 7: Respostas referentes ao campo "Outros" utilizada pelos respondentes quando perguntados sobre a característica mais chamativa em uma embalagem de lasanha pronta. 


\section{Outro}

\section{A integridade da embalagem}

\section{Preço}

Tabela 8: Respostas referentes ao campo "Outros" utilizada pelos respondentes quando perguntados sobre a característica mais chamativa em uma embalagem de nuggets.

Após estes levantamentos, também questionei se eles aceitariam trocar sua marca favorita por uma com uma embalagem mais prática através da pergunta "Você consideraria comprar um produto que não seja da sua marca preferida por conta de uma embalagem mais prática da concorrência?" e podemos ver a resposta no Gráfico 6:

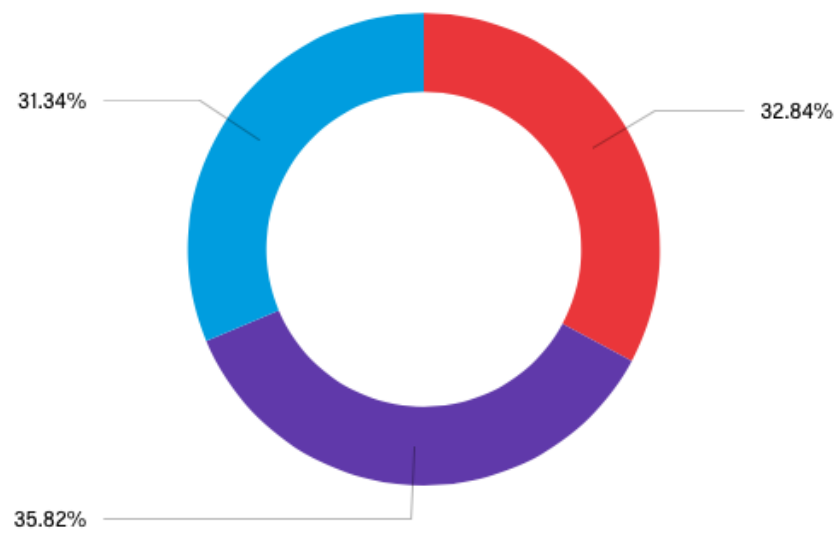

Sim Talvez não

Gráfico 6: Respostas da pergunta "Você consideraria comprar um produto que não seja da sua marca preferida por conta de uma embalagem mais prática da concorrência?".

Para finalizar a pesquisa, falei que a Sadia havia mudado a embalagem da sua lasanha pronta e do seu nuggets e questionei se eles sabiam dessa mudança e se isso interferiria no comportamento de compras deles por meio da pergunta "Você sabia que recentemente a embalagem da lasanha e do nuggets 
da Sadia sofreram grandes alterações para aumentar a praticidade do consumidor no momento de compra/ armazenar?" e veremos o resultado no Gráfico 7 abaixo:

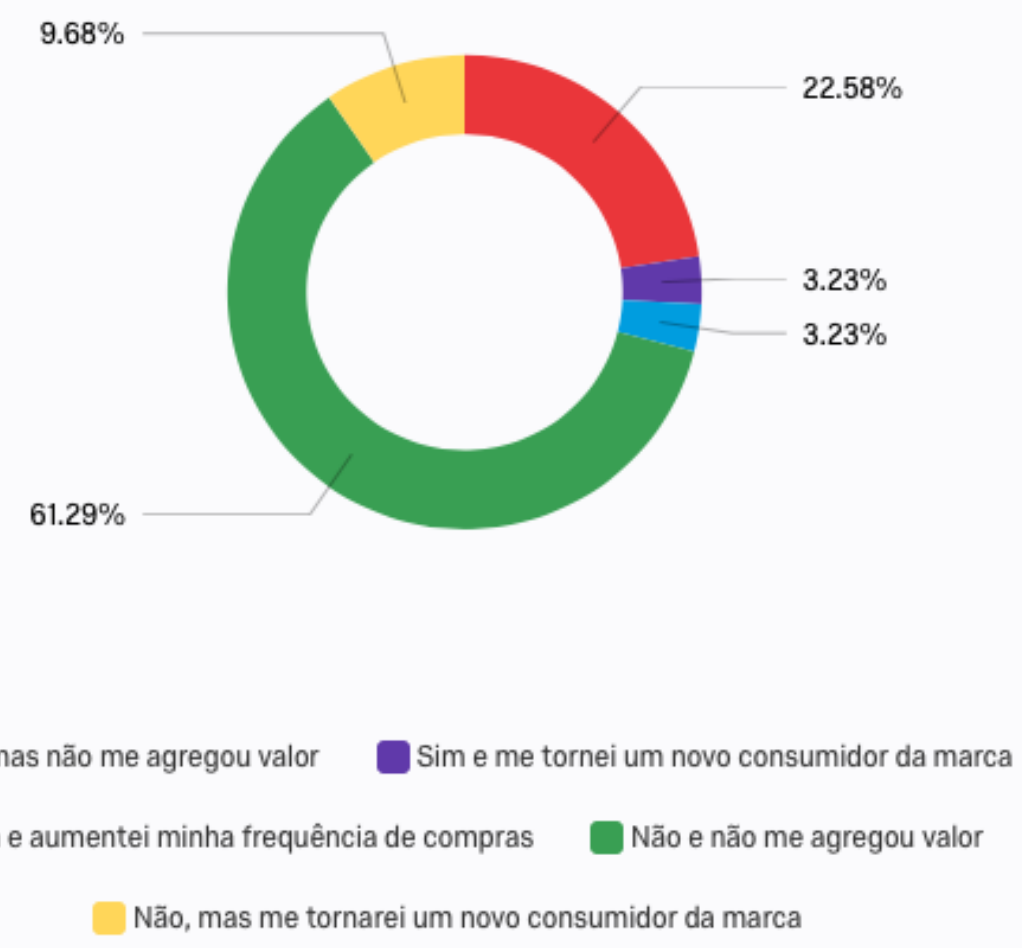

Gráfico 7: Resposta da pergunta "Você sabia que recentemente a embalagem da Lasanha e do nuggets da Sadia sofreram grandes alterações para aumentar a praticidade do consumidor no momento de compra/ armazenar?"

\subsection{Análise dos resultados}

Analisando as caraterísticas dos entrevistados, podemos ver no Painel 1 que $62 \%$ deles eram homens, quase metade (45\%) possuem entre 19 e 25 anos, o que faz sentido quando olhamos a Tabela 1 e vemos que $39 \%$ dos entrevistados eram estudantes. Quanto à renda, temos um equilíbrio entre as faixas de renda a partir da segunda categoria (2.001 - 5.000 reais até 20.001 reais ou mais) com aproximadamente $20 \%$ para cada categoria.

Para interpretar as 2 primeiras perguntas, foi separado a leitura delas de duas maneiras: se a descrição dos entrevistados estava de acordo com a nova embalagem da Sadia (podendo ser sim caso positivo, neutro caso não citasse nenhuma característica relevante para a análise e não caso estivesse de acordo com a embalagem antiga) e se a descrição fazia referência à Sadia (podendo ser 
sim caso positivo, neutro caso não citasse nenhuma característica relevante para a análise e não caso remetesse ao concorrente). Podemos ver na Tabela 8 as respostas que fazem referência à nova embalagem da lasanha da Sadia, na tabela 9 as que fazem referência à antiga embalagem da lasanha ainda utilizada pela concorrência e na Tabela 10 as respostas que fazem referência à Sadia. $\mathrm{Na}$ Tabela 11 vemos as respostas que fazem referência à antiga embalagem do nuggets da Sadia, na Tabela 12 as respostas que fazem referência à antiga embalagem utilizada pela concorrência, na Tabela 13 vemos as respostas que fazem referência à Sadia e na Tabela 14 as respostas que fazem referência à concorrência. Nos Gráficos 8 e 9 podemos ver um resumo de como as respostas foram classificadas:

\begin{tabular}{|c|l|}
\hline $\begin{array}{c}\text { Número } \\
\text { de } \\
\text { respostas }\end{array}$ & \multicolumn{1}{|c|}{ Q1 - Descreva brevemente uma embalagem de lasanha pronta que você compra no mercado. } \\
\hline 1 & De palstico e facil de abrir, \\
2 & Embalagem plastica, fácil de abrir, que não molha com a humidade do freezer \\
3 & Embalagem de papel plastificado e plástico transparente para tampar, \\
4 & Embalagem de plastico retangular com imagem da lasanha, \\
5 & Embalagem plastica por fora, embalagem interna de papel com tampa de papel ou plastico. \\
\hline
\end{tabular}

Tabela 8: Respostas da pergunta "Descreva brevemente uma embalagem de lasanha pronta que você compra no mercado" que fazem referência à nova embalagem de lasanha da Sadia.

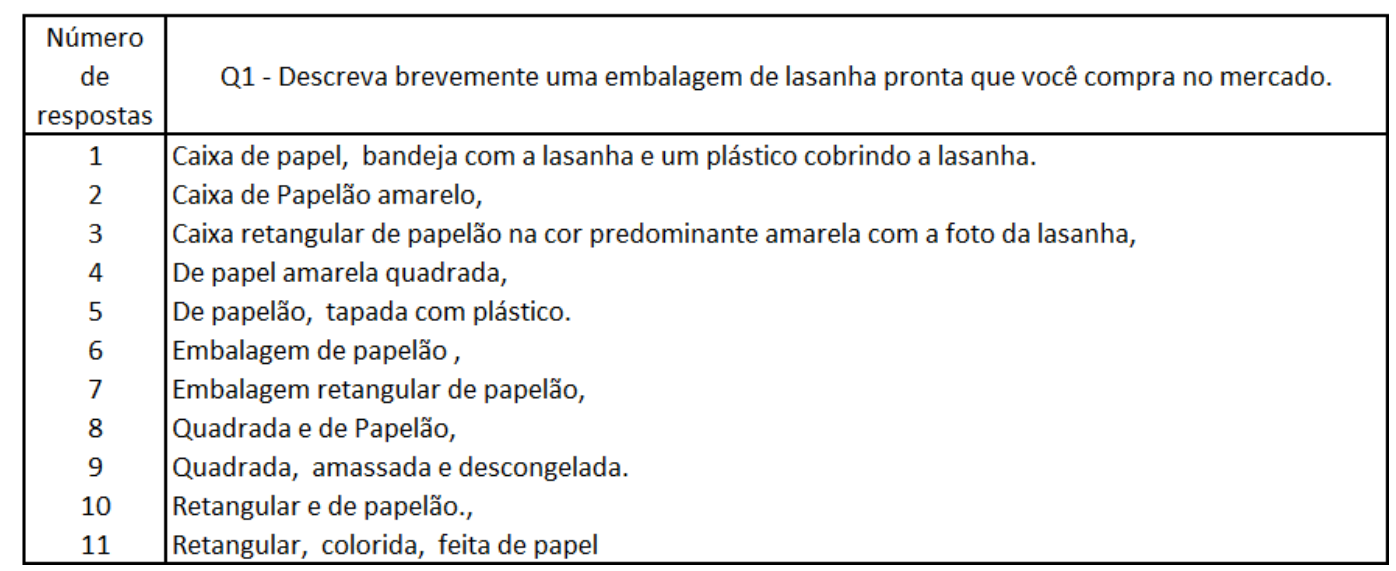

Tabela 9: Respostas da pergunta "Descreva brevemente uma embalagem de lasanha pronta que você compra no mercado" que fazem referência à antiga embalagem de lasanha ainda utilizada pela concorrência. 


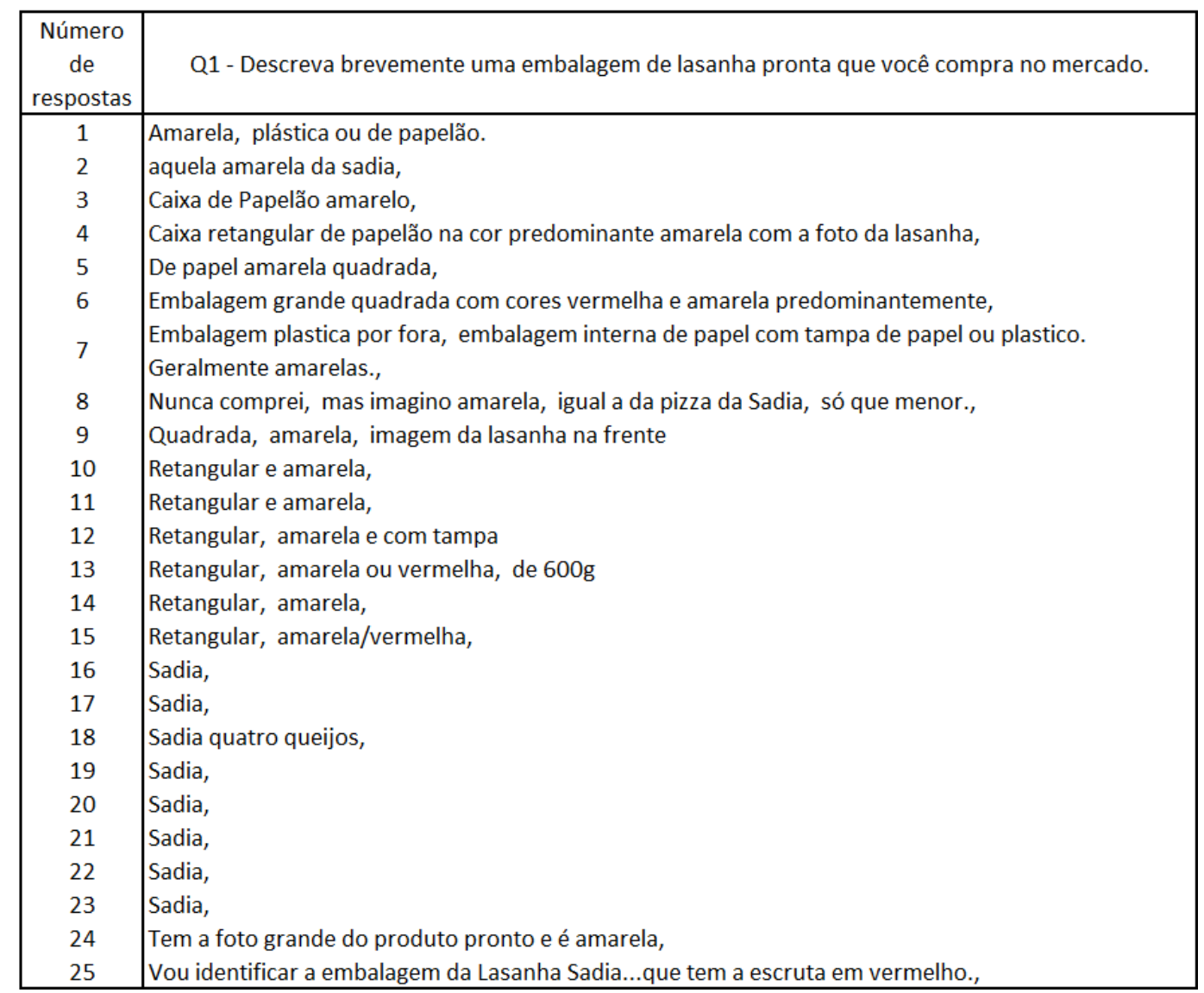

Tabela 10: Respostas da pergunta "Descreva brevemente uma embalagem de lasanha pronta que você compra no mercado" que fazem referência à Sadia.

\begin{tabular}{|c|l|}
\hline $\begin{array}{c}\text { Número } \\
\text { de } \\
\text { respostas }\end{array}$ & \multicolumn{1}{|c|}{ Q2 - Descreva brevemente uma embalagem de nuggets que você compra no mercado. } \\
\hline 1 & Embalagem plastica \\
2 & Caixa retangular ou saco plastico. \\
3 & Saco plastico \\
4 & Pacote \\
\hline
\end{tabular}

Tabela 11: Respostas da pergunta "Descreva brevemente uma embalagem de nuggets que você compra no mercado" que fazem referência à nova embalagem da Sadia. 


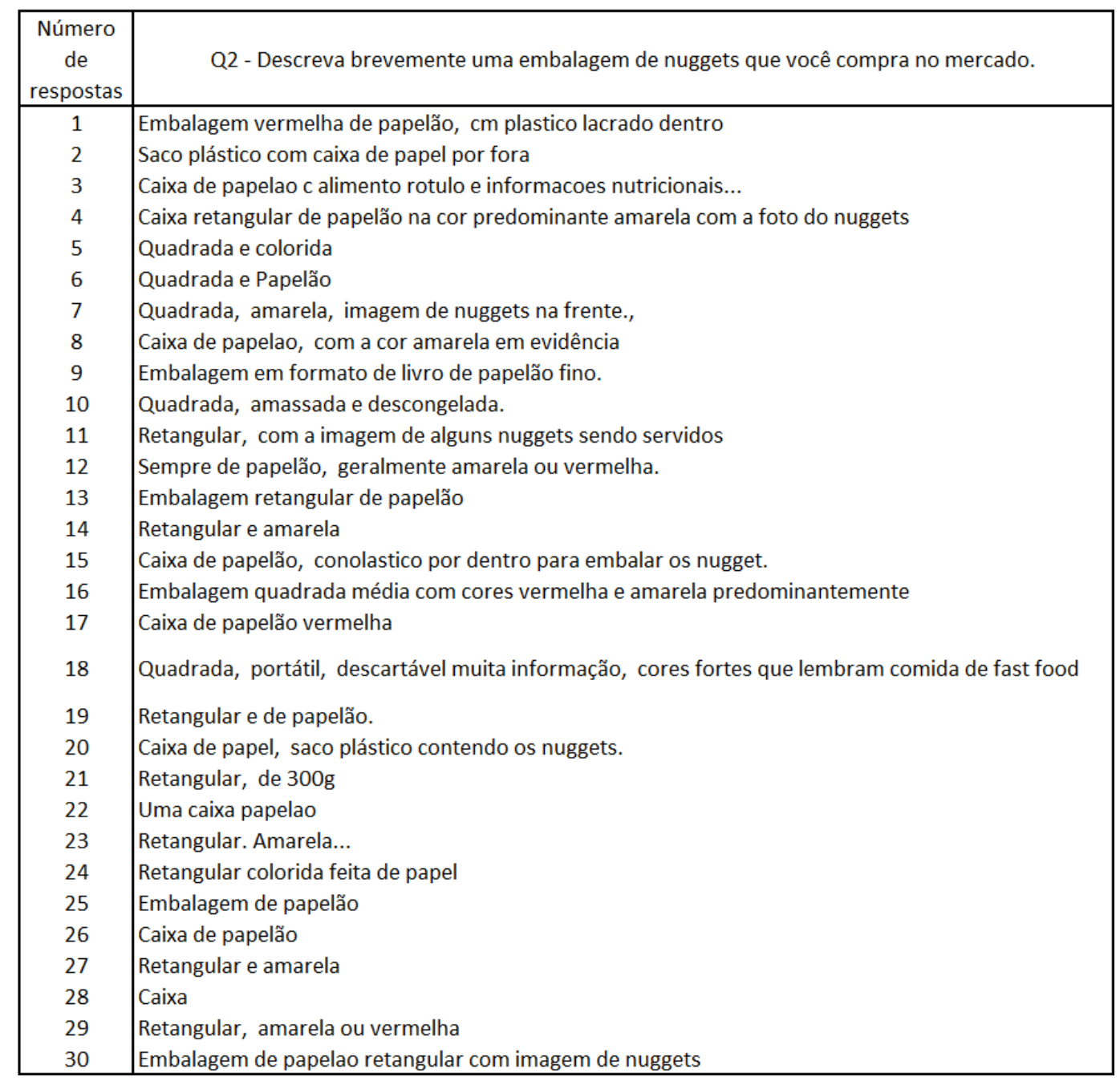

Tabela 12: Respostas da pergunta "Descreva brevemente uma embalagem de nuggets que você compra no mercado" que fazem referência à antiga embalagem ainda utilizada pela concorrência.

\begin{tabular}{|c|l|}
\hline $\begin{array}{c}\text { Número } \\
\text { de } \\
\text { respostas }\end{array}$ & \multicolumn{1}{|c|}{ Q2 - Descreva brevemente uma embalagem de nuggets que você compra no mercado. } \\
\hline 1 & Sadia \\
2 & Novamente me reporto a Sadia....letras vermelhas. \\
3 & Caixa retangular de papelão na cor predominante amarela com a foto do nuggets \\
4 & Sadia \\
5 & Quadrada, amarela, imagem de nuggets na frente., \\
6 & Caixa de papelao, com a cor amarela em evidência \\
7 & Da Sadia \\
8 & Sadia \\
9 & Tem varios nuggets prontos e amarela \\
10 & Retangular e amarela \\
11 & Embalagem quadrada média com cores vermelha e amarela predominantemente \\
12 & Sadia \\
13 & Retangular. Amarela... \\
14 & aquela amarela da sadia \\
15 & Sadia \\
16 & Retangular e amarela \\
17 & Sadia \\
18 & Sadia \\
\hline
\end{tabular}


Tabela 13: Respostas da pergunta "Descreva brevemente uma embalagem de nuggets que você compra no mercado" que fazem referência à marca Sadia.

\begin{tabular}{|c|l|}
\hline $\begin{array}{c}\text { Número } \\
\text { de } \\
\text { respostas }\end{array}$ & \multicolumn{1}{|c|}{ Q2 - Descreva brevemente uma embalagem de nuggets que você compra no mercado. } \\
\hline 1 & $\begin{array}{l}\text { Embalagem vermelha de papelão, cm plastico lacrado dentro } \\
2\end{array}$ \\
Caixa de papelão vermelha \\
\hline
\end{tabular}

Tabela 14: Respostas da pergunta "Descreva brevemente uma embalagem de nuggets que você compra no mercado" que fazem referência à concorrência.

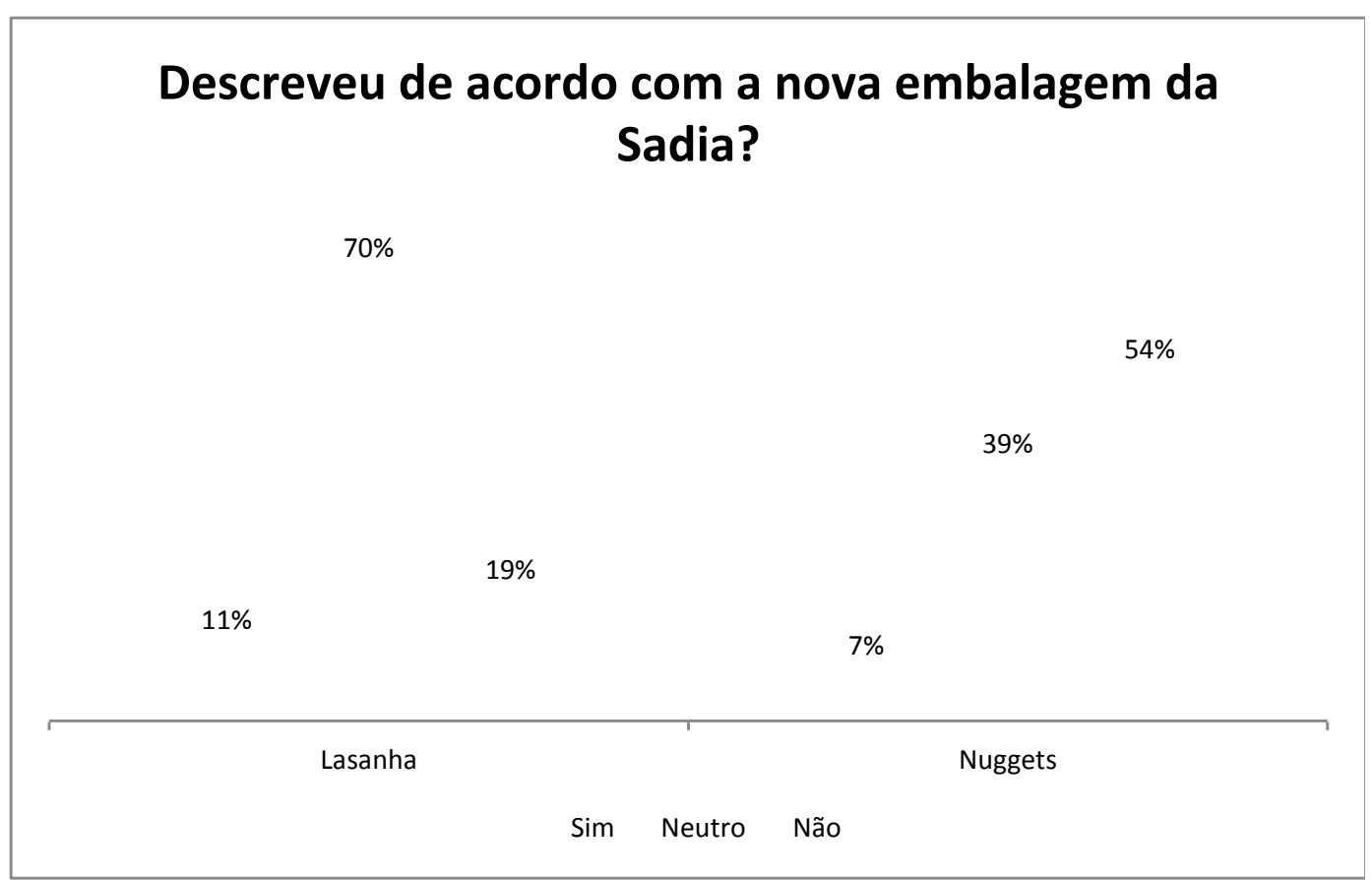

Gráfico 8: Análise se os consumidores descreveram a embalagem de acordo com a nova embalagem da Sadia. 


\section{O entrevistado descreveu a embalagem com características da Sadia?}

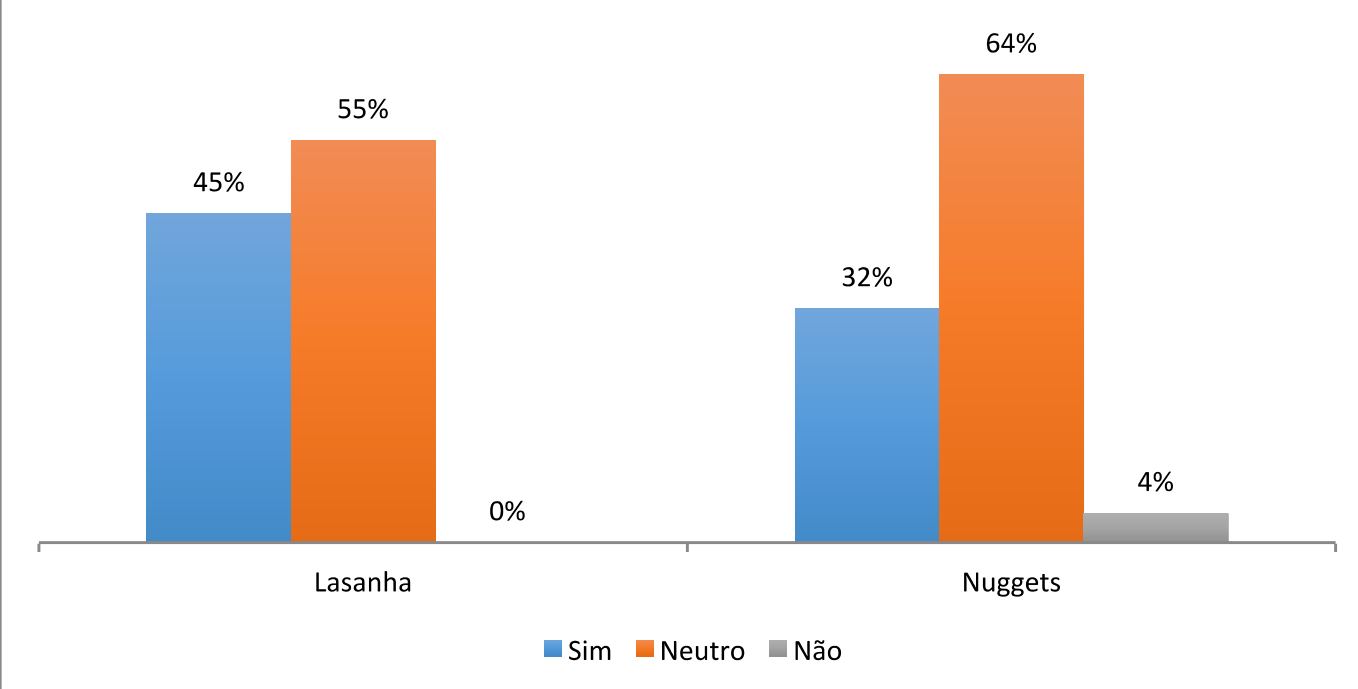

Gráfico 9: Análise se os consumidores descreveram a embalagem de acordo com alguma característica genérica da Sadia.

Por meio dos Gráficos 8 e 9 podemos identificar alguns comportamentos dos consumidores. Começando pelas lasanhas, vemos que apenas $11 \%$ descreveram a embalagem nova enquanto $19 \%$ descreveram a embalagem antiga, mas quando procuramos referências à Sadia, independente da nova embalagem, vemos que $45 \%$ dos entrevistados o fazem, mesmo sem ter lido nada referente à marca nesta etapa da pesquisa, enquanto nenhum entrevistado faz referência aos concorrentes. Agora analisando a descrição dos nuggets, vemos que apenas $7 \%$ dos consumidores fazem referência à nova embalagem da Sadia enquanto 54\% (mais da metade dos consumidores entrevistados) fazem referência à embalagem antiga e ainda utilizada pelos seus principais concorrentes, mas quando olhamos para referências a marcas, apenas 4\% descrevem características dos concorrentes enquanto $32 \%$ fazem referências a Sadia.

Por meio destes números anteriormente citados, também podemos perceber que $36 \%$ dos entrevistados que descreveram a embalagem de lasanhas prontas com alguma característica que nos permitiu identificar se ele fazia referência à embalagem antiga ou à nova da Sadia descreveu a embalagem como a nova. Enquanto isso, quando olhamos para as descrições das embalagens de nuggets, isso aconteceu apenas em $14 \%$ dos casos, o que nos leva a crer que os consumidores vêm tendo mais dificuldade em se adequar 
à embalagem dele, principalmente por ela ter sofrido a maior alteração entre as duas.

Indo para a frequência de compras dos entrevistados (Gráfico 2), podemos ver que 64\% dos entrevistados compra pelo menos entre 1 a 2 vezes por mês, nos confirmando o dado citado anteriormente que $61 \%$ dos brasileiros consomem alimentos congelados.

Quando questionados de maneira genérica sobre quais características da embalagem mais chamam sua atenção quando vão às compras no mercado (Tabela 6), vemos que as características que mais se encontram presentes no penúltimo e último lugar são o material da embalagem e o formato da embalagem respectivamente. Ao cruzarmos esta informação com as respostas das perguntas de o que mais chama a atenção deles quando vão comprar lasanhas prontas e nuggets no mercado (Gráfico 4 e Gráfico 5) vemos que em ambas as perguntas a segunda resposta mais presente é "a tradicional embalagem de papelão" ( $23 \%$ e $25 \%$ respectivamente). Isso demonstra que para estes dois produtos específicos o consumidor já tem uma imagem pré-definida de suas embalagens, fazendo com que, pelo conceito de "Similaridade" citado anteriormente, as novas embalagens da Sadia possam confundir seus consumidores por serem diferentes dos demais produtos similares da concorrência. Outra informação relevante são as respostas no campo "Outros". Em ambas as perguntas tivemos uma resposta em cada referente à integridade da embalagem, o que foi um dos principais motivos para a Sadia realizar esta alteração. Além disso, vemos que a resposta mais presente nas duas perguntas foi "alguma marca específica" (44\% para lasanha e 39\% para nuggets), mostrando que os clientes valorizam mais as suas marcas preferidas do que o formato da embalagem, o mix de sabores disponíveis, o espaço na gôndola destinado à uma determinada marca, as informações nutricionais e/ou o peso do produto.

Para finalizar a análise, quando questionados se a mudança recente na embalagem da lasanha pronta e do nuggets da Sadia interferiria no processo decisório de compras deles obtive a resposta de que $83 \%$ dos entrevistados não mudariam seus hábitos de compra por conta desta alteração. Olhando para este número, podemos chegar à conclusão de que a mudança da embalagem foi uma inovação contínua, visto que a influência no comportamento do consumidor não existiu praticamente. 


\section{Conclusões}

Devido ao aumento exponencial de estímulos que recebemos nos dias de hoje, empresas vem buscando se aprofundar cada vez mais neste conceito onde os consumidores prezam cada vez mais por experiências do que apenas pelo produto em si. Pensando nisso, a Sadia desenvolveu novas embalagens mais práticas para sua linha de produtos congelados e neste artigo vimos como seu consumidor interpretou esta alteração para suas lasanhas prontas e seus nuggets.

Analisando todas as informações coletadas, podemos chegar à conclusão que pelo menos $1 / 3$ dos consumidores estão familiarizados com a nova embalagem das lasanhas prontas, o que é um número satisfatório, visto que a Sadia tem $32 \%$ do mind share de comidas congeladas. Enquanto isso, apenas $14 \%$ estão familiarizados com as novas embalagens dos nuggets, percentual este abaixo do share da Sadia, demonstrando que o fato da embalagem dos nuggets ter sofrido mais alterações se comparada com a embalagem antiga, faz com que o tempo necessário para adaptação dos consumidores seja maior.

Além do fato da necessidade de aprendizado por parte dos consumidores, como vimos anteriormente, $83 \%$ da amostra estudada disse que não mudaria os hábitos de compra por causa da nova embalagem e aproximadamente 1/4 dos consumidores de ambos os produtos os identifica pela tradicional embalagem de papelão.

Concluindo, do ponto de vista de percepção dos seus consumidores, a nova embalagem das lasanhas prontas não afetou o mind share da Sadia nesta categoria e ao mesmo tempo ela teve ganhos com a troca da embalagem, ajudando seus promotores na área de vendas e seus consumidores finais no armazenamento do produto em casa, porém na categoria de nuggets, apesar dos benefícios para o armazenamento físico que a nova embalagem trouxe, a Sadia teve seu share afetado negativamente, logo a mudança de embalagem foi mal comunicada com o público e o mesmo precisará de mais tempo para se adaptar à nova embalagem. 


\section{Referências Bibliográficas}

AVELLAR E DUARTE. Gestalt- Percepção em contexto. Avellar e Duarte, 2015, disponível em: http://www.avellareduarte.com.br/layout/gestalt-percepcao-emcontexto/ Acesso em: 20 fev. 2018.

AVICULTURA INDUSTRIAL. Sadia comemora 70 anos de história, Avicultura Industrial, 2016. Disponível em:

https://www.aviculturaindustrial.com.br/imprensa/sadia-comemora-70-anos-dehistoria/20140609-083115-u710 Acesso em: 10 out. 2017.

DINO. Mercado de congelados cresce no Brasil junto aos investimentos desse novo negócio, InfoMoney, 2017. Disponível em:

http://www.infomoney.com.br/negocios/noticiascorporativas/noticia/6782616/mercado-congelados-cresce-brasil-junto-aosinvestimentos-desse-novo-negocio . Acesso em: 05 out. 2017.

EMBALAGEM MARCA 212. Substituição de embalagens pela Sadia deve transformar categoria de congelados, Embalagem Marca 212, 2017. Disponível em:

https://www.embalagemmarca.com.br/2017/06/substituicao-de-embalagenscartonadas-por-flexiveis-pela-sadia-deve-transformar-categoria-de-congelados/ . Acesso em: 10 out. 2017

HISRICH, R. D.; PETERS, M. P.; SHEPHERD, D. A. Empreendedorismo. 9. ed. Porto Alegre: AMGH, 2014. 480 páginas.

KOTLER; KELLER, Administração de Marketing. 14.ed. São Paulo, Pearson Education do Brasil, 2012. 765 páginas.

MIRAGAIA, M. Pesquisa de Marcas Top of Minds na Categoria de Alimentos Folha de S. Paulo, São Paulo, 10 out. 2017. Disponível em:

http://www1.folha.uol.com.br/topofmind/2017/10/1930604-ninho-vigor-sadia-e- 
qualy-se-destacam-em-alimentacao-no-top-of-mind.shtml. Acesso em: 8 mar. 2018.

SOLOMON, Consumer Behavior: Buying, Having and Being. 10.ed. Nova Jersey, Prentice Hall, 2012. 614 páginas.

VERGARA, Projetos e Relatórios de Pesquisa em Administração. 5.ed. São Paulo, Editora Atlas S.A., 2004. 93 páginas. 